\title{
Intellectual Capital, Members' Participation and Cooperative Performance: The Mediating Role of Management Capabilities
}

\author{
Suraiya Ishak ${ }^{1}$, Ahmad Raflis Che Omar ${ }^{2}$, Sarmila Md Sum ${ }^{1}$, Azhar Ahmad ${ }^{2}$, Abd Hair Awang ${ }^{1} \&$ Abdullah Sanusi \\ Othman $^{2}$ \\ ${ }^{1}$ Faculty of Social Sciences and Humanities, Universiti Kebangsaan Malaysia, Bangi, Malaysia \\ ${ }^{2}$ Faculty of Economics and Management, Universiti Kebangsaan Malaysia, Bangi, Malaysia \\ Correspondence: Ahmad Raflis Che Omar, Faculty of Economics and Management, Universiti Kebangsaan Malaysia, \\ Bangi, Malaysia. Tel: 60-3-8921-3419.
}

Received: August 13, 2020

doi:10.5430/rwe.v12n1p252
Accepted: October 19, 2020

Online Published: January 10, 2021

URL: https://doi.org/10.5430/rwe.v12n1p252

\begin{abstract}
The purpose of this paper is to validate the mediating effect of management capability/capabilities (MC) on the relationships between intellectual capital (IC) and cooperative members' participation (MP) and the cooperatives' financial and non-financial performance. The major aim is to examine the effect of $\mathrm{MC}$ in mediating the relationship between influential antecedents and cooperative performance - a topic that is relatively understudied in the literature. The study employs the survey technique to gather data from the respondents. Therefore, the questionnaire is designed to measure the indicators of the prescribed independent and dependent variables. The independent variables consist of MP and IC, which is further itemised into structural capital (SC), human capital (HC) and relational capital (RC), whilst the dependent variable consists of performance measured by financial and non-financial indicators. The questionnaires are distributed to 234 cooperatives that consist of palm oil smallholders cooperatives in Peninsular Malaysia. Among the targeted sample, $44 \%$ responded to the survey. The relationships between the characteristics of the Board of Directors and performance are validated through the partial least squares analysis. The findings indicate MC is a significant mediator in the relationships between IC and MP and cooperative performance. Furthermore, MC has been found to have a positive effect on the financial and non-financial performance of the cooperatives. IC and MP have indirect effects on cooperative performance. The ability to influence such a performance lies in the abilities of the management to optimise the benefits obtained from the SC, HC and RC and MP in the cooperative's activities.
\end{abstract}

Keywords: cooperative, intellectual capital, members' participation, management capabilities, performance, RBV

\section{Introduction}

A cooperative is a self-managed business entity that belongs to a group of people having a homogeneous background. Such an organisation, inspired by the 'Robert Owen Village', aims to protect the common interests of a specific group of individuals. There are seven principles associated with cooperatives, and these reflect the collective movement to improvise the 'unfriendly scenario or unfair treatment' of the free market towards the target group of people based on the principle of equality of rights. According to Mahazril 'Aini et al. (2012) and Ortmann and King (2007), cooperatives are established to improve the well-being of the members, eradicate poverty and serve as an alternative platform to distribute the national wealth amongst the people. Cooperatives are described as user-owned and user-controlled businesses that distribute benefits equitably based on the usage or patronage of the members (Ortmann and King 2007). Therefore, agricultural-based cooperatives are crucial in enhancing and protecting the interest of farmers within the agricultural sector.

Cooperatives play a critical role in improving the living conditions of the members, particularly those in the low-income groups, the rural people and the urban poor both in developing and developed countries (Sharma 2020; Kyriakarakos et al. 2020; Dorgi \& Gala 2016; Ojiagu et al. 2015; Kumar et al. 2015; Mahazril 'Aini, Hafizah \& Zuraini 2012; Mohamed Esham et al. 2012; Ortmann \& King 2007; and Ahmad Bello 2005). The emergence of the so-called 'new generation cooperatives' (NCGs) has motivated cooperative managers to modify their business strategy and approaches. In other words, the rise of NGCs since 1988 has brought different foci into the efficient management of cooperatives (Ortmann \& King 2007). Such NGCs emphasise valued-added activities, thus creating a demand for an efficient and effective cooperative management similar to that found in the private sector. The intense 
competition in the market has also affected the performance management philosophy and strategies employed by cooperative managers. This is necessary, because cooperatives would have to participate in a typical market in order to deliver services effectively, whilst satisfying the members' needs. Hence, there is currently an overwhelming need to expand our understanding of cooperative performance and the potential determinants that influence such a performance (Ishak et al. 2020).

Performance barriers are often linked to the issue of scarce tangible assets in terms of financial, labour and other economic assets. Nevertheless, the resource-based view (RBV) postulates that intangible assets can outperform the competitive ability of the tangible assets in achieving superior performance (Khan et al. 2019; Hussain \& Waheed 2019; Adnan et al. 2018; and Hsu \& Wang 2010). Therefore, the popularity of the RBV has led to the recognition of intellectual capital (IC) as a crucial element in ensuring business sustainability in the 21st century (Hussain \& Waheed 2019). The RBV argues that firms have different resources and varying levels of capabilities (Adnan et al. 2018; and Nath et al. 2010). Furthermore, the resources and capabilities owned by the firms, creating what is known as the 'firm effect', enable the owners to perform better and gain more benefits based on the different performance levels (Basterretxea \& Martínez 2012). The effective management of valuable, rare and hard-to-imitate organisational assets can create above-average competitive ability for their possessor. This notion is supported by such scholars as Adnan et al. (2018); Kamukama et al. (2011) and Hassan et al. (2017), who argued that the key to a firm's success in a competitive environment is to employ resources that are unique and specific to that firm. Thus, IC serves as the determinant factor of organizational performance in the current environment.

Furthermore, in accordance with the RBV, members' participation (MP) is another unique element in cooperatives that can be potentially maximised to achieve good performance. According to Grauvilardell (2013), cooperatives rely heavily on their members, thus there exists a direct link between MP and cooperative success. The low level of MP leads to the lesser degree of representation of their communities and the inability to address the needs and expectations of the community. It can also lead to the lack of economic participation, which inevitably affects financial support from the members and diminishes the cooperatives' ability to expand and achieve sustainability. Hence, the effective management of members' expectations and needs determines their engagement in cooperative activities.

Although IC and MP have been shown to influence cooperative performance (Sushila et al. 2009; Sharabati et al. 2010; Malina Hanum et al. 2012; Wang \& Cao, 2015; Hashim et al. 2015; Barkat \& Loo-See 2018; Kamukama et al. 2011), the relationship effect must be investigated more precisely. Such a need is justified as few studies have shown that the relationships are not direct. Based on Kamukama et al. (2011), Hsu and Wang (2010) and Hassan et al. (2017), the relationship is mediated by specific variables, including competitive advantage, dynamic capability, and operations capability and marketing capability. The inclusion of the mediating variable allows for a more meaningful explanation related to the 'process' or how the effect is accrued. This is due to the fact that the benefits brought about by intangible assets, such as IC and MP, are subjected to certain capabilities possessed by the organisation. For example, the cooperative may have members who are willing and ready to participate in the cooperative activities. However, their real involvement remains subjected to the cooperative management's capability to induce their intention or interest to participate. Hence, mediating variable that potentially affect the relationship within the context of smallholders' palm oil cooperatives must be investigated. The inclusion of the mediating factor enables the 'input-process-output' perspective to describe the proposed relationship between cooperative performance, on the one hand, and IC and MP, on the other hand. Furthermore, the researchers of contemporary strategic management are keen on identifying the 'mechanism' that explains how the possession of strategic resources can improve organisational performance (Hassan et al. 2017; and Monday et al. 2015). In this sense, the integration of the mediating variable definitely clarifies such a curiosity.

As a far as the RBV is concerned, cooperative survival greatly depends on the ability to create new resources that build on its internal capabilities and on making the capabilities more inimitable in order to achieve competitive advantage and superior performance. This reiterates the fact that the possession of resources does not guarantee superior performance. This idea is parallel to that of Huang et al. (2012), who suggested that resources alone cannot provide an advantage to the organisation unless the management has the relevant capability to transform them into the desired outcomes. As a result, studies on performance must emphasise resource allocation, effective utilisation and management, all which refer to MC. Based on Khan et al. (2109), dynamic managerial capabilities enable the business enterprises to create, allocate, and protect their intangible assets to support superior long-run business performance. Management with managerial capabilities are able to identify new threats and opportunities and to integrate new ideas and knowledge with existing capabilities to achieve superior performance. 
Therefore, the current study aims to investigate the effect of MC in the relationship between IC and MP and the financial performance (FP) and non-financial performance (NFP) of cooperatives. The major aim is to validate the role of MC as the mediating factor between cooperative performance and IC and MP-a topic that has been relatively understudied in the literature.

\section{Literature Review}

\subsection{Resource Based View (RBV)}

Recently, the intangible resources have frequently acknowledged as a valuable element for creating superior performance compared to the typical tangible resources (Sardo and Serrasqueiro, 2017; and Adnan et al. 2018). Most of the intangible resources are internally developed or/and nurtured, thus making it exclusive to the owners. Consequently, the RBV gain enormous attention as the underlying theory for explaining the relationship between unique intangible resources and organisations' performance. The Resource Based View (RBV) emphasize on implementing strategies to enhance performance by optimizing the internal-based resources (Ramon-Jeronimo et al. 2019). The RBV proponents believe that organisations which are able to exploit their internal intangible resources and continually maintaining it have more strength to beat the competitors in marketplace. Nevertheless, not all resources have significant relationship with performance. According to RBV, the resources must embrace four important attributes, i.e. valuable, rare, inimitable and non-substitutable (VRIN) in order to create superior competitive advantages as well as to improve firms' efficiency and effectiveness (Adnan et al. 2018; Hussain \& Waheed 2019; Ramon-Jeronimo et al. 2019; and Khan et al. 2019). Thus, the study was built on the premise that IC, MP and MC are the intangible resources that potentially influence cooperatives performance according to the notion of RBV.

\subsection{Intellectual Capital and Members' Participation}

Currently, most of the strategic management practitioners and academics are focusing on an important intangible asset known as IC. IC refers to all resources that are relevant to the creation of enterprise value, but do not appear in the traditional balance sheet, unlike the monetary or physical assets. IC is a form of intangible asset that can be optimised to create sustainable advantage for its owners (Hussain \& Waheed 2019; Vrontis et al. 2010; Malina Hanum et al. 2012; Maduenyi et al. 2015; Galati et al. 2017; Barkat \& Loo See 2018). Many studies have investigated the relationship between IC and firm performance (Sushila et al. 2009; Sharabati et al. 2010; Malina Hanum et al. 2012; Wang \& Cao, 2015; Hashim et al. 2015; Maduenyi et al. 2015; Maditinos et al. 2010; Barkat \& Loo-See 2018; Kamukama et al. 2011; Liang et. al 2015; Benos et al. 2016, Hafizah et al. 2016; Scafarto et al. 2016; Ahmed et al. 2019; and Hussain \& Waheed 2019). The IC consists of structural capital (SC), human capital (HC) and relational capital (RC), which are used to create value for the attainment of cooperative performance (Malina Hanum et al. 2012; Wang \& Cao 2015; Scafarto et al. 2016). SC refers to the exclusive possession of knowledge by the particular cooperative, such as the effective database, organisational culture and efficient procedures. Meanwhile, RC refers to the benefits arising from the cooperative's relationship with its customers, suppliers and other constituencies, which enable the former to perform tasks/transactions better than their competitors. HC refers to the possession of knowledge, skills and commitment by the cooperative workers, which allow them to perform the necessary tasks on behalf of the cooperatives.

The cooperative model refers to an autonomous association of persons united voluntarily to meet their common economic, social and cultural needs and aspirations through a jointly owned and democratically controlled enterprise (Grauvilardell 2013). As a result, cooperatives rely heavily on their members, which highlight the direct link between MP and cooperative success (Grauvilardell 2013; and Ismail et al. 2019). As far as MP is concerned, a low level of MP leads to a lesser degree of representation in their communities, the inability to address the right needs and expectations of the community and the lack of economic participation, which inevitably affects financial support from the members and diminishes the expansion ability of the cooperatives. MP refers to the act of taking part in any activity of the society by all members of the cooperative (Dorgi \& Gala 2016; Ismail et al. 2019). Active and strong support from the members is significant in achieving good cooperative performance (Ismail et al. 2019; Olabisi \& Petronilla 2011; Mahazril 'Aini et al. 2012).

\subsection{Capabilities}

Capability is defined as the ability of a firm to use its resources 'to affect a desired end' (Nath et al. 2010). Furthermore, Nath et al. (2010) elaborated on capabilities as the tangible or intangible organisational processes developed by a firm over a period of time, which cannot be easily bought as they are built internally. Firm capabilities are the key determinants of financial performance across industries and firms. These capabilities include 
collective ideas as well as knowledge and activities that directly translate a firm's vision and mission into concrete actions that produce financial results (Joyce \& Slocum 2012). According to Hassan et al. (2017), organisational capability is the ability of the organisation to deploy its resources to perform activities or tasks that can enhance its performance. The ability of an organisation to execute a coordinated set of tasks and utilise organisational resources towards the achievement of a performance goal is the gist of organisational capability. Generally, organisations have varying levels of organisational capabilities which, in turn, lead to performance variations.

Organisational capabilities are divided into three types (Hassan et al. 2017). The zero-level capabilities, known as operational capabilities, refer to all capabilities that allow an organisation to sustain operations in the present and existing situation. The first-level capabilities or dynamic capabilities, refers to the changes and modifications of the zero-level capabilities. Meanwhile, the higher-order capabilities or regenerative dynamic capabilities operate on the first-level capabilities. The higher-order capabilities involve a broader set of decision options that goes beyond ordinary routines and existing conditions.

Various types of capabilities have been discussed in previous studies, including operational capabilities (Nath et al. 2010; Hassan et al. 2017), dynamic capabilities (Yao-Pin Peng et al. 2019; Mikalef \& Pateli 2017; Hsu \& Wang 2010; Winter 2003); export capabilities (Ramon-Jeronimo et al. 2019) and marketing capabilities (Nath et al. 2010). Operational capabilities are considered as the first type of organisational capability (Hassan et al. 2017). The operational capability is defined as the ability of an organisation to improve its business process, making it more effective and efficient with minimum wastage of resources. The organisational performance is improved through a distinctive method of allocation, coordination and utilisation of resources resulting from the operational capabilities. The operating capabilities allow an organisation to carry out its main operating activities on a regular basis by supporting existing products and providing services to current customers (Mikalef \& Pateli 2017). Operational capabilities enable an organisation to gain advantage in its value-creation activity business process, which depend upon the elements of cost efficiency, speed and quality. Meanwhile, dynamic capabilities are considered as first-level capabilities expanded from the basic, zero-level capability (Winter 2003). Dynamic capabilities are organisational routines that facilitate the accumulation of knowledge via learning processes. It is described as 'learning mechanism that guides knowledge creation'. Therefore, organisational learning mechanism is important in understanding firms' capabilities and potential to address challenges and changes in their environment (Hsu \& Wang 2010; Mikalef \& Pateli 2017). Based on Hsu and Wang (2010), dynamic capabilities allow IC to influence organisational performance through the accumulation and enhancement of R\&D and marketing capabilities. Many studies have investigated the relationship between IC and firm performance (Sushila et al. 2009; Sharabati et al. 2010; Malina Hanum et al. 2012; Wang \& Cao, 2015; Hashim et al. 2015; Maduenyi et al. 2015; Maditinos et al. 2010; Barkat \& Loo-See 2018; Kamukama et al. 2011; Liang et. al 2015; Benos et al. 2016, Hafizah et al. 2016; Scafarto et al. 2016; Ahmed et al. 2019). The IC consists of structural capital (SC), human capital (HC) and relational capital (RC), which are used to create value for the attainment of cooperative performance (Malina Hanum et al. 2012; Wang \& Cao 2015; Scafarto et al. 2016). SC refers to the exclusive possession of knowledge by the particular cooperative, such as the effective database, organisational culture and efficient procedures. Meanwhile, RC refers to the benefits arising from the cooperative's relationship with its customers, suppliers and other constituencies, which enable the former to perform tasks/transactions better than their competitors. HC refers to the possession of knowledge, skills and commitment by the cooperative workers, which allow them to perform the necessary tasks on behalf of the cooperatives.

Multi-dimensional operational capability features three core capabilities: technical/technological, marketing and managerial capabilities. Technical or technological capability is related to the operational aspect of the organisation, enabling it to become more efficient and effective in terms of reducing errors and enhancing the quality of business process execution. Marketing capability is defined as the process through which an organisation selects the intended value propositions for their target customers and deploys organisational resources to deliver these value offerings in pursuit of its desired goals. Meanwhile, managerial capability is the ability of the managers to participate actively in the business activities of the organisation and direct organisational resources towards achieving set goals. Marketing capabilities are featured in an integrative process in which a firm uses its tangible and intangible resources to understand complex consumer needs, achieve product differentiation relative to the competition and achieve superior brand equity (Nathe et al. 2010). A firm develops its MC when it is able to combine the individual skills and knowledge of its employees along with its available resources. Finally, operations capability refers to the integration of a complex set of tasks performed by a firm to enhance output through the most efficient utilisation of its production capabilities, technology and flow of materials (Nath et al. 2010).

Management refers to a process of coordinating resources through the functions of planning, organising, leading and controlling in order to attain specific objectives. It requires the use of different capabilities, which affect the 
achievement of the determined objective(s) (i.e. performance). Management with sufficient capabilities can effectively deploy organisational resources and manage an organisational environment towards the achievement of superior performance (Basterretxea \& Martínez 2012; Jolly et al. 2016). MC refers to the abilities of managing resources, creating a strategic vision and identity for the company, communicating these throughout the organisation and encouraging the workforce to achieve them. Based on Jolly et al. (2016), MC consists of five elements: competence, cooperation, commitment, information and communication technology (ICT) and task methodology. Jolly et al. (2016) found that MC positively relates to project performance. Additionally, a study by Monday et al. (2015) found a significant relationship between the strategic management and corporate performance of selected manufacturing firms in Nigeria. Thus, strategic management can be considered a critical factor in ensuring good organisational performance. Based on Monday et al. (2015), we believe that strategic MC is the advanced part of MC that is linked to the process of establishing an organisation's long-term direction, setting specific performance objectives, developing strategies to achieve the objectives under all relevant internal and external circumstances and executing the chosen action plans. It does not merely consist of making strategic decisions but also taking the necessary actions to implement the decisions effectively.

As far as organisational capability is concerned, we argue that zero-level capability is the most appropriate one to be considered within the context of agriculture cooperatives in developing countries. This is in conjunction with the situation faced by most agriculture cooperatives in such countries with the aim of resolving the basic socio-economic issues faced by the rural farmers. The cooperatives activities range within the scope of basic activities underlying its establishment motive, which are mainly to protect and to uphold the interests of the farmers through relevant and necessary services (Ojiagi et al. 2015; Kumar et al. 2015; Ahmad Bello 2005; Torgerson et al. 1997). Therefore, our study suggested the use of MC as a more relevant mediating factor between cooperative performance and IC and MP. It has been suggested that MC can manage the existing operation (operational capabilities) and the deployment of cooperative resources, thus leading to differences in the contributions of IC and MP to cooperative performance. Based on the entire argument presented in the literature review, we posited that $\mathrm{MC}$ is a crucial factor in determining the influences of MP, SC, HC and RC on cooperative performance. The ability to deploy internal resources and strengths are pivotal to ensuring the impact of MP, SC, HC and RC on cooperative performance. We argue that the effects of SC, HC, RC and MP require the help of MC in order to organise and coordinate the entire organisation towards performance accomplishment. Therefore, MC mediates the relationship between performance and MP, HC, $\mathrm{SC}$ and RC, as depicted in Figure 1.

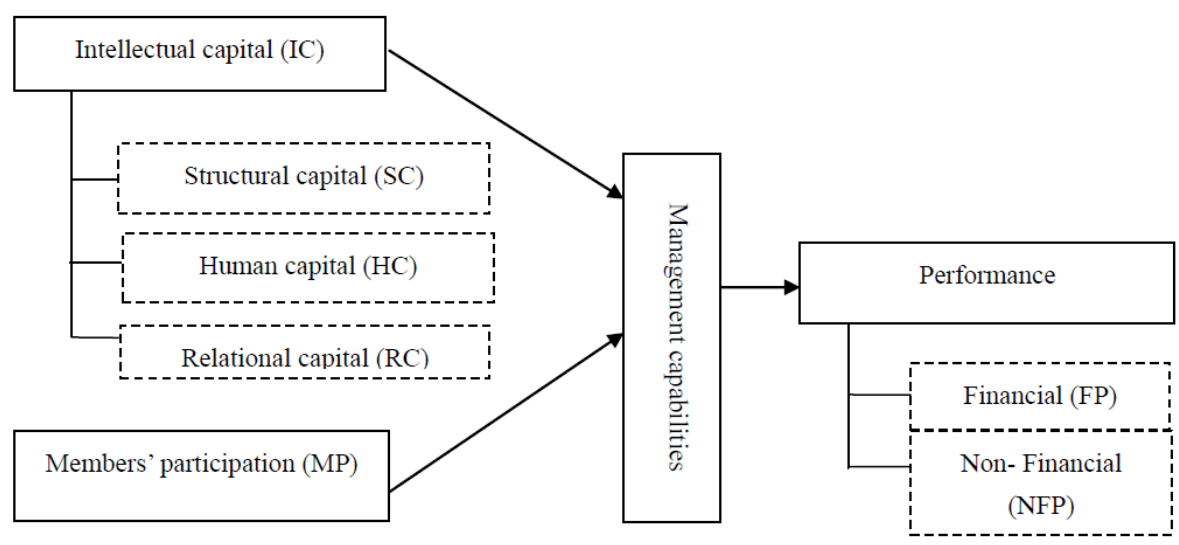

Figure 1. Research framework

As far as MC is concerned, we propose the integration of the RBV as the theoretical basis for cooperative performance. Such a perspective recognises the role of internal resources and capabilities to create competitive advantage in the marketplace (Wang 2014; Barney 1991). The RBV contends that organisational resources are more valuable than the industry structure. Researchers subscribing to the RBV argue that only strategic elements (i.e. core distinctive competencies and strategic assets) are considered as useful resources and competencies for creating competitive advantage (Ahmed et al. 2019; Wang 2014; Madhani 2010; Barney 1991). Strategic management researchers use the RBV to understand inter-differences in performance, suggesting that firm performance is largely 
due to the ownership of unique resources that cause differences in productivity levels (Nath et al. 2010; Mikalef \& Pateli 2017). The RBV analyses and interprets organisational resources in order to understand firm performance due to the presence of any sustainable competitive advantage. Furthermore, cooperatives' capabilities to deploy resources are more critical to performance attainment. Hafizah et al. (2016) and Liang et al. (2015) examined the influence of intangible factors on cooperative performance. The intangible factors refer to MC in several aspects: (1) managing IC, (2) encouraging active MP and (3) executing social roles efficiently. Thus, the RBV fits the expected relationship, as shown in Figure 1.

Based on the information present above, the following hypotheses are proposed:

Ha1: A relationship exists between MC and cooperative FP.

Ha2: A relationship exists between MC and cooperative NFP.

Ha3: A relationship exists between SC and MC.

Ha4: A relationship exists between inter-organisational RC and MC.

Ha5: A relationship exists between $\mathrm{HC}$ and MC.

Ha6: A relationship exists between MP and MC.

\section{Methods}

\subsection{Research Design}

The sample was drawn from the list of palm oil smallholders' cooperatives provided by the official database of the Malaysia Cooperative Societies Commission (SKM). The sampling frames consisted of 234 cooperatives formed by palm oil smallholders in Peninsular Malaysia. A questionnaire was developed and distributed through the Regional Officer of SKM in each state. The questionnaires were answered by the representative of the board (consisting of the Chairman, Secretary or Treasurer). A total of 108 questionnaires (46\%) were received from the respondents, but 4 were excluded because of incomplete information. Finally, we came up with 104 (44\%) questionnaires that were used for further analysis. Table 1 presents the demographic profiles of the respondents.

Table 1. Respondents profiles

\begin{tabular}{lll}
\hline Respondents' Profiles: & Frequencies & Percentage (\%) \\
$\mathbf{n = 1 0 4}$ & 17 & 16 \\
\hline Parent Agency's: & 57 & 55 \\
MPOB & 30 & 29 \\
FELDA & & \\
FELCRA & 76 & 73 \\
\hline Number of managerial employees: & 7 & 7 \\
1-5 persons & 2 & 2 \\
6-10 persons & - & - \\
11-15 persons & - & - \\
16-20 persons & 1 & 1 \\
$21-25$ persons & 18 & 17 \\
26-30 persons & & \\
No information & 36 & 35 \\
\hline Number of operational (site) employees: & 12 & 12 \\
$1-5$ persons & 7 & 7 \\
$6-10$ persons & 2 & 2 \\
$11-15$ persons & & \\
$16-20$ persons & &
\end{tabular}




\begin{tabular}{lll}
\hline $21-25$ persons & 1 & 1 \\
$26-30$ persons & 3 & 3 \\
$31-35$ persons & 1 & 1 \\
$36-40$ persons & - & - \\
$41-45$ persons & 2 & 2 \\
$46-50$ persosn & 1 & 1 \\
$51-55$ persons & - & - \\
$56-60$ persons & 1 & 1 \\
No information & 38 & 36 \\
\hline
\end{tabular}

\subsection{Measurement and Procedures}

A questionnaire was developed to measure all the identified independent and dependent variables. The IC was measured according to three separate dimensions (HC, SC and RC). The SC section measured the existence and the state of cooperatives' internal structure to assist the implementation of activities and management. The HC section measures the competencies and attitudes of the workers or subcontractors in performing business routines effectively. $\mathrm{RC}$ was measured by the inter-organisational element in order to evaluate the contribution of external networks in supporting cooperative activities efficiently. Furthermore, the relationship with governing agencies was measured to evaluate the influence of such a relationship on cooperative performance. Additionally, the MP was measured to identify the level of members' involvement in various activities organised by the cooperatives. The respondents gave responses using a 6- point Likert scale with answers ranged from (1) strongly disagree to (6) strongly agree. The mediating variable of MC was computed from the means of items under each independent variable, which consisted of MP, SC, HC and RC. Meanwhile, the dependent variable of cooperative performance was measured by two dimensions: cooperative FP and NFP. All answers were also given based on the same 6-point Likert scale.

The questionnaire development followed a similar process as that detailed in Hafizah et al. (2016). However, their measurement was relatively general, as their study did not focus on any specific type of cooperative. Thus, modifications and adjustments were made to fit the context of the current study (i.e., palm oil smallholders' cooperatives) (Ishak et al. 2020). The questionnaire was pilot-tested to 17 cooperatives from similar backgrounds. The reliability test alpha values ranged from 0.805 to 0.979 , indicating good consistency (see Table 2 for the results).

Table 2. Reliability Test Result

\begin{tabular}{lll}
\hline Sub Section & Measures & Cronbach alpha \\
\hline D1 & Structure Capital (SC) & 0.936 \\
\hline D2 & Relational Capital (with external constituencies) $\left(\mathrm{RC}_{1}\right)$ & 0.825 \\
\hline D3 & Employees Effciency $\left(\mathrm{HC}_{1}\right)$ & 0.933 \\
\hline D4 & Employees Attitude $\left(\mathrm{HC}_{2}\right)$ & 0.968 \\
\hline D5 & Members' participation & 0.930 \\
\hline D6 & Relationship Capital (parent agencies control) $\left(\mathrm{RC}_{2}\right)$ & 0.805 \\
\hline E1 & Performance (financial) & 0.979 \\
\hline E2 & Performance (Non financial) & 0.932 \\
\hline
\end{tabular}

Regression or difference of means tests (e.g., ANOVA or t-tests) is suitable for testing different modelling scenarios. However, according to Yänẽz-Araque et al. (2017) the techniques offer limited modelling capabilities, particularly in terms of causal or complex modelling. Thus, the alternative approach of SEM allows for relatively complex models that include latent (unobserved) variables and chains of effects (mediation), as is the case at hand. Specifically, the SEM analysis can be carried out via one of two distinct statistical techniques: the method based on the analysis of covariance (factors), i.e. covariance-based SEM (CB-SEM) and another based on variance (or components), i.e. 
partial least squares (PLS) (Lowry \& Gaskin 2014). According to Yảnẽz-Araque et al. (2017), in choosing whether to use CB-SEM or PLS, the decision largely depends on the type of the study conducted. If the study is exploratory in nature, one should choose PLS, whilst for confirmatory study, one can either use the CB-SEM or PLS. Additionally, PLS is most suitable when the analysis uses a relatively small sample, when the data are not normally distributed and/or when the models are highly complex with multi-dimensional constructs. The current study employs PLS-SEM similar to the approach of Yảnẽz-Araque et al. (2017). This is because our study aims to explore the relationship based on the RBV postulation within a different organisational context (i.e. cooperatives in developing countries).

\section{Results}

First-order reflective latent variables were subjected to reliability, convergent validity and discriminant validity tests. Table 3 shows the Cronbach's alpha (CA), composite reliability (CR) and average variance extracted (AVE) values for all factors. The CA values range between 0.828 and 0.953 , thus showing that all factor items correlate strongly to each other and are reliable (Hair et al. 2007). Meanwhile, the CR test results indicate that all factors have consistent values with the CA. The CA and CR values are all above the threshold of 0.70 , suggesting acceptable construct reliability (Nunnally 1978). Meanwhile, the convergent validity was assessed by examining the AVE, with results indicating that the values ranged from 0.617 to 0.836 . Convergent validity was also assessed by examining whether the AVE was above the lower limit of 0.50 (Fornell \& Larcker 1981). Based on Table 3, all the loadings, CR and AVE values are higher than the recommended threshold. Therefore, the final model is considered satisfactory, indicating that all items are good indicators for their respective latent variables.

Table 3. Construct reliability and validity

\begin{tabular}{|c|c|c|c|}
\hline Factors & $\begin{array}{l}\text { Cronbach's Alpha } \\
\text { (CA) }\end{array}$ & $\begin{array}{l}\text { Composite Reliability } \\
\text { (CR) }\end{array}$ & $\begin{array}{l}\text { Average Variance } \\
\text { Extracted (AVE) }\end{array}$ \\
\hline Employee Attitude & 0.934 & 0.953 & 0.836 \\
\hline Employee Efficiency & 0.921 & 0.944 & 0.809 \\
\hline External Relations & 0.918 & 0.936 & 0.711 \\
\hline Financial Performance & 0.953 & 0.961 & 0.753 \\
\hline Human Capital & 1.000 & 1.000 & 1.000 \\
\hline Management & 1.000 & 1.000 & 1.000 \\
\hline Members' Participation & 0.903 & 0.926 & 0.679 \\
\hline Non-Financial Performance & 0.911 & 0.927 & 0.617 \\
\hline Parent Agency Control & 0.828 & 0.885 & 0.659 \\
\hline Relational Capital & 1.000 & 1.000 & 1.000 \\
\hline Structural Capital & 0.921 & 0.935 & 0.645 \\
\hline
\end{tabular}

Based on Table 4, the values of the diagonals are all greater than the value of inter-construct correlations, thereby indicating that the constructs in this study are distinct and reveal adequate discriminant validity. The results signify that the measurement model can be considered satisfactory owing to the reliability of the discriminant validity results. 
Table 4. Discriminant validity

\begin{tabular}{|c|c|c|c|c|c|c|c|c|c|c|c|}
\hline & 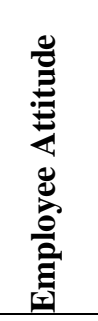 & 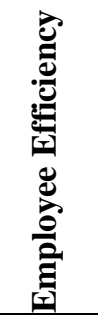 & 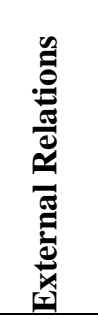 & 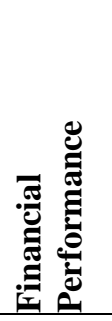 & 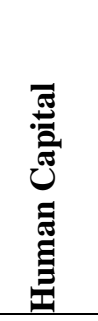 & 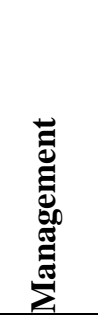 & 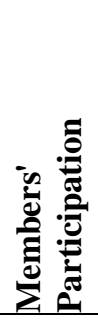 & 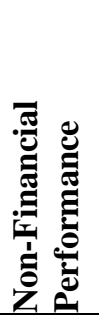 & 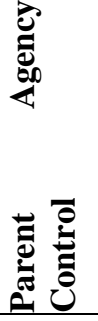 & 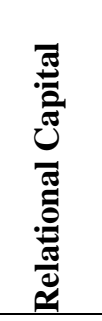 & 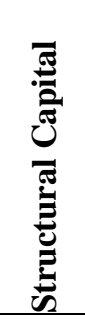 \\
\hline Employee Attitude & 0.914 & & & & & & & & & & \\
\hline Employee Efficiency & 0.741 & 0.899 & & & & & & & & & \\
\hline External Relations & 0.648 & 0.625 & 0.843 & & & & & & & & \\
\hline Financial Performance & 0.559 & 0.386 & 0.451 & 0.868 & & & & & & & \\
\hline Human Capital & 0.834 & 0.832 & 0.683 & 0.508 & 1.000 & & & & & & \\
\hline Management & 0.861 & 0.778 & 0.824 & 0.647 & 0.879 & 1.000 & & & & & \\
\hline Members' Participation & 0.719 & 0.615 & 0.668 & 0.622 & 0.715 & 0.839 & 0.824 & & & & \\
\hline $\begin{array}{l}\text { Non-Financial } \\
\text { Performance }\end{array}$ & 0.580 & 0.414 & 0.398 & 0.710 & 0.533 & 0.621 & 0.591 & 0.785 & & & \\
\hline Parent Agency Control & 0.343 & 0.193 & 0.378 & 0.488 & 0.289 & 0.611 & 0.386 & 0.402 & 0.912 & & \\
\hline Relational Capital & 0.588 & 0.458 & 0.744 & 0.572 & 0.563 & 0.851 & 0.598 & 0.505 & 0.883 & 1.000 & \\
\hline Structural Capital & 0.653 & 0.604 & 0.747 & 0.549 & 0.675 & 0.850 & 0.660 & 0.504 & 0.448 & 0.694 & 0.803 \\
\hline
\end{tabular}

Table 5 presents the results of the hypothesis testing. The coefficient of determination or $\mathrm{R}^{2}$, path coefficient and $\mathrm{t}$-value of the hypothesised relationship were calculated to evaluate the significance of the relationship (see Table 5). The results indicated $\mathrm{R}^{2}$ values of 0.414 and 0.380 for the outcome factor of cooperative FP and NFP, respectively.

The results also suggest the existence of direct significant relationships between MC and FP $(\beta=0.647 ; t=11.066, p$ $=0.000, \mathrm{p}<0.05)$ and MC and NFP $(\beta=0.621 ; \mathrm{t}=9.837, \mathrm{p}=0.000, \mathrm{p}<0.05)$. The results indicate that the MC has a positive and significant relationship with both cooperative FP and NFP.

Table 5. Direct relationship

\begin{tabular}{llllll}
\hline Relationship & Coefficient & $\begin{array}{l}\text { Standard } \\
\text { Deviation }\end{array}$ & $\begin{array}{l}\text { T } \\
\text { Statistics }\end{array}$ & $\begin{array}{l}\text { Palues } \\
\text { VIF }\end{array}$ \\
\hline Relation between External Relations $\rightarrow$ Relational Capital & 0.479 & 0.033 & 14.594 & 0.000 & 1.323 \\
\hline $\begin{array}{l}\text { Relation between Independent of Parent Agency Control } \\
\rightarrow \text { Relational Capital }\end{array}$ & 0.702 & 0.047 & 14.897 & 0.000 & 1.323 \\
\hline R Square & 0.976 & & & & \\
\hline R Square Adjusted & 0.975 & & & & \\
\hline Relation between Employee Attitude $\rightarrow$ Human Capital & 0.541 & 0.030 & 18.093 & 0.000 & 2.220 \\
\hline Relation between Employee Efficiency $\rightarrow$ Human Capital & 0.531 & 0.018 & 29.273 & 0.000 & 2.220 \\
\hline R Square & 1.000 & & & & \\
\hline R Square Adjusted & 1.000 & & & & \\
\hline $\begin{array}{l}\text { Relation between Structural Capital (SC) } \rightarrow \text { Management } \\
\text { Capabilities (MC) }\end{array}$ & 0.187 & 0.010 & 18.095 & 0.000 & 2.735 \\
\hline $\begin{array}{l}\text { Relation between Relational Capital (RC) } \rightarrow \text { Management } \\
\text { Capabilities (MC) }\end{array}$ & 0.375 & 0.027 & 14.161 & 0.000 & 2.867 \\
\hline
\end{tabular}




\begin{tabular}{|c|c|c|c|c|c|}
\hline $\begin{array}{l}\text { Relation between Human Capital (HC) } \rightarrow \text { Management } \\
\text { Capabilities (MC) }\end{array}$ & 0.390 & 0.030 & 13.142 & 0.000 & 2.463 \\
\hline 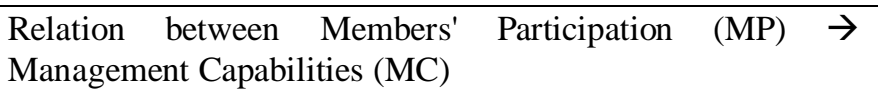 & 0.212 & 0.014 & 15.288 & 0.000 & 2.483 \\
\hline R Square & 1.000 & & & & \\
\hline R Square Adjusted & 1.000 & & & & \\
\hline $\begin{array}{l}\text { Relation between Management } \quad \text { Capabilities } \quad(\mathrm{MC}) \rightarrow \\
\text { Financial Performance }(\mathrm{FM})\end{array}$ & 0.647 & 0.059 & 11.066 & 0.000 & 1.000 \\
\hline R Square & 0.419 & & & & \\
\hline R Square Adjusted & 0.414 & & & & \\
\hline $\begin{array}{l}\text { Relation between Management Capabilities }(\mathrm{MC}) \rightarrow \\
\text { Non-Financial Performance (NFP) }\end{array}$ & 0.621 & 0.063 & 9.837 & 0.000 & 1.000 \\
\hline R Square & 0.386 & & & & \\
\hline R Square Adjusted & 0.380 & & & & \\
\hline
\end{tabular}

The findings also show the existence of direct significant relationships between SC and MC $(r=0.187 ; t=18.095, p$ $=0.000, \mathrm{p}<0.05), \mathrm{RC}$ and $\mathrm{MC}(\beta=0.375 ; \mathrm{t}=14.161 \mathrm{p}=0.000, \mathrm{p}<0.05) ; \mathrm{HC}$ and $\mathrm{MC}(\beta=0.390 ; \mathrm{t}=13.142, \mathrm{p}=$ $0.000, \mathrm{p}<0.05)$ and MP and MC $(\beta=0.212 ; \mathrm{t}=15.288, \mathrm{p}=0.000, \mathrm{p}<0.05)$. The results indicate that all the three components of IC and MP have positive relationships with MC. The structural model from PLS is summarised in Figure 2 .

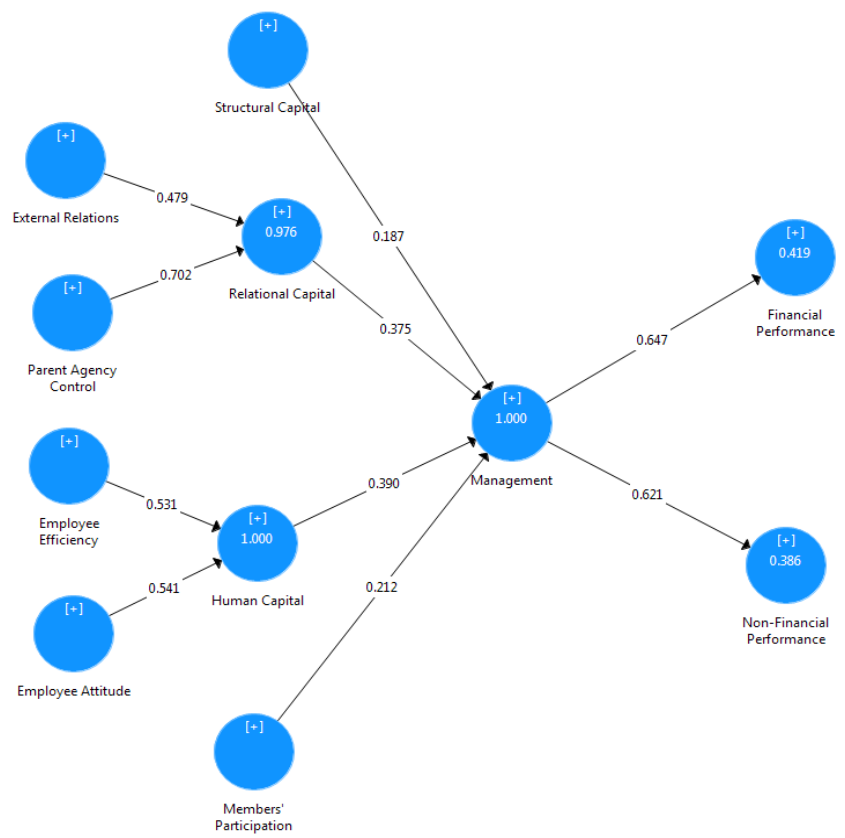

Figure 2. The relationship between IC, MP, MC and cooperative performance

Table 6 summarises the results of the hypotheses test. 
Table 6. Hypoteses test results

\begin{tabular}{lll}
\hline Hypotheses & Test of Relationships & Results \\
\hline $\begin{array}{l}\text { Ha1: There is a relationship between management capabilities and } \\
\text { financial performance. }\end{array}$ & $\mathrm{MC} \rightarrow \mathrm{FP}$ & Supported \\
\hline $\begin{array}{l}\text { Ha2: There is a relationship between management capabilities and } \\
\text { non-financial performance. }\end{array}$ & $\mathrm{MC} \rightarrow \mathrm{NFP}$ & Supported \\
\hline $\begin{array}{l}\text { Ha3: There is a relationship between SC and management } \\
\text { capabilities. }\end{array}$ & & Supported \\
\hline $\begin{array}{l}\text { Ha4: There is a relationship between relational capital (RC) and } \\
\text { management capabilities } \rightarrow \mathrm{MC}\end{array}$ & Supported \\
\hline $\begin{array}{l}\text { Ha5: There is a relationship between HC and management } \\
\text { capabilities } \rightarrow \mathrm{MC}\end{array}$ & Supported \\
\hline $\begin{array}{l}\text { Ha6: There is a relationship between members' participation and } \\
\text { management capabilities }\end{array}$ & $\mathrm{MP} \rightarrow \mathrm{MC}$ & Supported \\
\hline
\end{tabular}

\section{Discussion}

Cooperatives are neither government agencies nor charitable non-profit organisations (NGOs). Cooperatives are unique entities as they are owned, managed and controlled by the members themselves. In general, cooperative can be described as the organisation of solidarity that aim to protect the interests of people having similar backgrounds. As a result, cooperative movements have contributed to the improvement of the living conditions of the members, particularly the low-income groups, rural households and urban poor (Sharma 2020; Kyriakarakos et al. 2020; Esim, 2014; Dorgi \& Gala 2016; Ojiagu et al. (2015); Mahazril 'Aini, Hafizah \& Zuraini 2012; Ahmad Bello 2005). All cooperatives have their own organisational structure led by a body of members elected as the Board of Directors (BOD). The BOD is the responsible working body that formulates plans in accordance with the decisions made by the general body. The managing committee is accountable to the general body of members. In order to execute the implemented decisions or plans, the cooperatives organise specific bureaus or committees to assist in day-to-day operations under the direct supervision of the BOD. In terms of the board structure, about $63 \%$ of the cooperatives indicate that they have assigned the operations according to specific units or committees. The cooperative BOD directly leads and monitors the implementation of specific task according to the unit/committees. On the basis of the practices implemented by the palm oil smallholders, the Chairman, Secretary and Treasurer are frequently assigned to lead and monitor important units within the cooperatives' operations.

Based on our study, the respective BOD directly manages the cooperative management business according to the agreed resolution from the body of members. The permanent employees are relatively few (see Table 1) and mostly assist in basic operations, such as clerical work and store maintenance. Therefore, in this context, MC is closely related to the BOD's ability to deploy and manage the cooperatives' tangible and intangible assets at the strategic, business and tactical levels. Based on the findings, the scope of the BOD's responsibilities is relatively broader than that of the BODs in investor-owned companies. Within the context of investor-owned entities, BOD management capabilities are more into strategic aspects, whilst most business and tactical discretions are made by the management team. Therefore, MC within the context of palm oil smallholders' cooperatives actually refers to the MC of the cooperatives' BODs. Such BODs with sufficient MC are able to create positive impact on both the FP and NFP of the cooperatives. The impact is justified by the RBV argument that management capability is crucial in determining the positive impact of SC, $\mathrm{HC}, \mathrm{RC}$ and MP on cooperative performance. This is parallel with the ideas of Basterretxea and Martínez (2012) and Jolly et al. (2016), who emphasised that management with good capabilities is more capable of deploying organisational resources and managing the organisational environment towards the achievement of superior performance. As far as cooperatives are concerned, MC also determines MP in cooperative activities. According to Grauvilardell (2013), MP is crucial for cooperative success. Therefore, cooperative management must possess the capability to foster a supportive atmosphere and environment that promotes MP and loyalty.

In terms of specific findings on IC, we provide support to the previous findings of Hafizah et al. (2016), Hashim et al. (2015), Barkat and Beh (2018) and Scafarto et al. (2016), who all argued that IC has a significant influence on cooperative performance. Nevertheless, our finding is distinct in that it reveals that the effect took place through the 
role of MC. This finding reiterates that merely owning some strategic resources does not guarantee an impact on cooperative performance. Furthermore, the possession of rare and inimitable resources is meaningless without the $\mathrm{MC}$ that can extract the best value from the internal resources. For example, human capital skills are meaningless if the management is unable to ensure that the employees utilise their knowledge and skills for the benefit of the cooperatives. Similarly, the cooperatives gain less from their structured working procedures unless the management can promote adherence to or compliance with the prescribed procedures. Moreover, the possession of good networks with external significant constituencies could not benefit the cooperatives if the management fails to take project opportunities from such valuable networks. As far as MP is concerned, the members may probably sabotage the cooperatives activities if the management fails to deliver the expected services/outcomes for the members. Therefore, the effects of SC, HC, RC and MP are to be expected through the mediation of MC, which specifically refers to the $\mathrm{MC}$ of the cooperatives' BODs.

\subsection{Conclusion and Implications}

Based on this study, future research that aim to understand the impact of IC on cooperative performance must consider the mediating effect of MC. The inclusion of MC allows a logical explanation that relates IC (consisting of SC, HC and RC) to organisational performance. Moreover, our study highlights the need for organisational behaviour researchers to expand investigations on IC and performance into the cooperative context. This is because cooperatives comprise one of the important entities that contribute significantly to the sustainable development agenda. Thus, studies on the determinants of cooperative performance, which consider the benefits of rare, uncommon and inimitable resources, are necessary in order to further improve their performance. Furthermore, similar studies on agricultural cooperatives within the context of developed nations can replicate our model by integrating the first-level capabilities or the dynamic capabilities as the mediating variable between IC and cooperative performance. This is due to the fact that agricultural cooperatives in developed countries, such as Japan, are probably exposed to relatively advanced issues, different scopes of management responsibilities and varying expectations compared to the cooperatives found in developing nations.

One of the practical implications of this work is educating cooperative members with relevant knowledge. This way, we can ensure the selection of management with the necessary capabilities to manage the cooperatives. This is in line with the nature of cooperative identity, which is essentially owned, self-managed and controlled by the members. The members must be sufficiently educated to allow them to contribute to the cooperatives - either through direct participation, such as serving as board members or service providers, or via indirect participation, such as users of cooperative products/services and sharers of constructive idea. In addition, cooperative members are part of the significant $\mathrm{HC}$, which is not only unique to the cooperatives but can also influence cooperative performance. As far as superior performance is concerned, competitive advantage is no longer determined by the possession of physical assets and/or financial capital alone; rather, through the optimisation of intellectual assets consisting of SC, $\mathrm{HC}$ and $\mathrm{RC}$.

\section{Acknowledgment}

The authors would like to thank MPOB-UKM Endowed Chair (EP-2017-055) for the funding of this research under EP-2017-055 research code commencing from December 2017 until June 2020. Additionally, we express our gratitude to Suruhanjaya Koperasi Malaysia (SKM) for assisting the research process.

\section{References}

Adnan, M., Abdulhamid, T., \& Sohail, B. (2018). Predicting firm performance through resource based framework. European Journal of Business and Management, 10(1), 31-40.

Ahmad Bello, D. (2005). The role of cooperative societies in economic development. Munich Personal RePec Archive (M|PRA). Paper no. 23161. Retrieved October 25, 2018, from http://mpra.ub.uni-muenchen.de/23161/

Ahmed, S. S., Guozhu, J., Mubarik, S., Khan, M., \& Khan, E. (2019). Intellectual capital and business performance: the role of dimensions of absorptive capacity. Journal of Intellectual Capital, 21(2), 23-39. https://doi.org/10.1108/JC-11-2018-0199

Barney, J. (1991). Firm resources and sustained competitive advantage. Journal of Management, 17(1), 99-119. https://doi.org/10.1177/014920639101700108

Basterretxea, I., \& Martínez, R. (2012). Impact of management and innovation capabilities on performance: are cooperatives different?. Annals of Public and Cooperative Economics, 83(3), 357-381. https://doi.org/10.1111/j.1467-8292.2012.00467.x 
Benos, T., Kalogeras, N., Verhees, F. J. H. M., Sergaki, P., \& Pennings, J. M. E. (2016). Cooperatives' organizational restructuring, strategic attributes, and performance: the case of agribusiness cooperatives in Greece. Agribusiness: An International Journal, 32(1), 127-149. https://doi.org/10.1002/agr.21429

Dorgi, O., \& Gala, G. (2016). Assessment of factors affecting members' participation in Fi-shery Cooperatives (The case of Gambella Region, Ethiopia). Journal of Business Management \& Social Sciences Research, 5(12), $347-36$.

Esham, M., Kobayashi, H., Matsumura, I., \& Alam, A. (2012). Japanese agricultural cooperatives at crossroad: a review. American-Eurasian Journal of Agricultural and Environmental Science, 12(7), 943-953.

Esim, S. (2014). The cooperative key to sustainable development. Retrieved December 7, 2019, from https://www.ilo.org/global/about-the-ilo/newsroom/news/WCMS_303222/lang--en/index.htm

Fornell, C., \& Larcker, D. F. (1981). Evaluating structural equation models with unobservable variables and measurement error. Journal of Marketing Research, 18(1), 39-50. https://doi.org/10.1177/002224378101800104

Galati, A., Cresimanno, M., \& Tinervia, S. (2017). Internal resources as tools to increase the global competition: the Italian wine industry case. British Food Journal, 119(11), 2406-2420. https://doi.org/10.1108/BFJ-02-2017-0092

Grauvilardell, E. (2013). Strengthening association: the key to cooperative success. Human Behavior/Strategy. Retrieved from https://filene.org/blog/strengthening-association-cooperative-success

Hassan, S., Mei, T. S., \& Johari, H. (2017). Mediating role of operational capabilities between intellectual capital and organizational performance: a proposed theoretical framework. Academy of Strategic Management Journal, $16(3), 1-12$.

Hsu, L. C., \& Wang, C. H. (2010). Clarifying the effect of intellectual capital on performance: the mediating role of dynamic capability. British Journal of Management. https://doi.org/10.1111/j.1467-8551-2010-00718.x

Huang, Y. C., Jim Wu, Y. C., \& Rahman, S. (2012). The task environment, resource commitment and reverse logistics performance: Evidence from the Taiwanese high-tech sector. Production Planning \& Control, 23(10-11), 851-863. https://doi.org/10.1080/09537287.2011.642189

Hussain, R. T., \& Waheed, A. (2019). Strategic resources and firm performance: An application of the Resource Based View. The Lahore Journal of Business, 7(2), 59-94. https://doi.org/10.35536/ljb.2019.v7.i2.a3

Ishak, S., Che Omar, A. R., Sum, S. Md., Othman, A. S., \& Jaafar, J. (2020). Smallholder agriculture cooperatives' performance: what is in the minds of management?. Journal of Co-operative Organization and Management, 8(2), 1-9. https://doi.org/10.1016/j.jcom.2020.100110

Ismail, M., Zainol, F. A., Yusoff, M. N. H., \& Che Rusuli, M. S. (2019). The driving forces of the business sustainability model among co-operatives in Malaysia. The Journal of Social Sciences Research, 5(3), 826-829. https://doi.org/10.32861/jssr.53.826.829

Jolly, B., Md Isa, F., Othman, S. N., \& Ahmdon, M. A. S. (2016). The influence of management capability, marketing capability and competitive advantage on Malaysian construction project performance. International Review of Management and Marketing, 6(S8), 142-148.

Joyce, W. F., \& Slocum, J. (2012). Top management talent, strategic capabilities, and firm performance. Organizatonal Dynamics, 41, 183-193. https://doi.org/10.1016/j.orgdyn.2012.03.001

Kamal, M. H. M., Mat, R. C., Rahim, N. A., Husin, N., \& Ismail, I. (2012). Intellectual capital and firm performance of commercial banks in Malaysia. Asian Economic and Financial Review, 2(4), 577-590.

Kamukama, N., Ahiauzu, A., \& Ntayi, J. M. (2011). Competitive advantage: mediator of intellectual capital and performance. Journal of Intellectual Capital, 12(1), 152-164. https://doi.org/10.1108/14691931111097953

Khan, K. U., Xuehe, Z., Atlas, F., \& Khan, F. (2019). The impact of dominant logic and competitive intensity on SMEs performance: A case from China. Journal of Innovation and Knowledge, 4(2019), 1-11. https://doi.org/10.1016/j.jik.2018.10.001

Kumar, V., Wankhede, K. G., \& Gena, H. C. (2015). Role of cooperatives in improving livelihood of farmers on sustainable basis. American Journal of Educational Research, 3(10), 1258-1266. 
Kyriakarakos, G., Balafoutis, A. T., \& Bochtis, D. (2020). Proposing a paradigm shift in rural electrification investments in Sub-Sharan Africa through agriculture. Sustainability, 12(8), 3-19. https://doi.org/10.3390/su12083096

Lowry, P. B., \& Gaskin, J. (2014). Partial least squares (PLS) structural equation modeling (SEM) for building and testing behavioral causal theory: when to choose it and how to use it. IEEE Transactions on Professional Communication, 57(2), 123-146. https://doi.org/10.1109/TPC.2014.2312452

Madhani, P. K. (2010). Resource Based View (RBV) of competitive advantage: an overview. In P. Madhani (Ed.), Resource based view: concepts and practices (pp. 3-22). Hyderabad India: Icfai University Press. Retrieved from http://ssrn.com/abstract=1578704

Maditinos, D., Ševic, Ž., \& Tsairidis, C. (2010). Intellectual capital and business performance: An empirical study for the Greek listed companies. European Research Studies, XIII(3), 145-167. https://doi.org/10.35808/ersj/291

Maduenyi, S., Oke, A. O., \& Fadeyi, O. (2015). Impact of organisational structure on organisational performance. International Conference on African development Issues (CU-ICADI) 2015-Social and Economic Models for Development Track (pp. 354-358). Retrieved from https://www.researchgate.net/publication/291336611_Impact_of_Organizational_Structure_on_Organizational_ Performance/link/56a0877808ae4af52549bf78/download

Mahazril Aini, Y., Hafizah, H. A. K., \& Zuraini, Y. (2012). Factors affecting cooperatives' performance in relation to strategic planning and members participation. Procedia-Social and Behavioral Science, 65(2012), 100-105. https://doi.org/10.1016/j.sbspro.2012.11.098

Mikalef, P., \& Pateli, A. (2017). Information technology-enabled dynamic capabilities and their indirect effect on competitive performance: Findings from PLS-SEM and fsQCA. Journal of Business Research, 70(2017), 1-16. https://doi.org/10.1016/j.jbusres.2016.09.004

Monday, J. U., Akinola, G. O., Ologbenla, P., \& Aladeraji, O. (2015). Strategic management and firm performance: a study of selected manufacturing companies in Nigeria. European Journal of Business and Management, 7(2), 161-172.

Nath, P., Nachiappan, S., \& Ramanathan, R. (2010). The impact of marketing capability, operations capability and diversification strategy on performance: a resource-based view. Industrial Marketing Management, 39(2010), 317-329. https://doi.org/10.1016/j.indmarman.2008.09.001

Nunnally, J. C. (1978). Psychometric theory 3E. Tata McGraw-Hill Education.

Ojiagu, N. C., Onugu, C., \& Uchenna. (2015). Effects of membership of cooperative organizations and determinants on farmer-members' income in rural Anambra State, Nigeria. International Journal of Scientific \& Technology Research, 4(8), 28-35.

Olabisi, T. A., \& Petronilla, O. I. (2011). Effect of members' participation on cooperative performance: a study of selected multipurpose cooperative societies (mcs) in Awka South Lga of Anambra State, Nigeria. International Journal of Multi-Disciplinary Research, iv(2011), 117-126.

Ortmann, G. F., \& King, R. P. (2007). Agricultural cooperatives 1: History, theory and problems. Agrekon, 46(1), 40-68. https://doi.org/10.1080/03031853.2007.9523760

Ramon-Jeronimo, J. M., Florez-Lopez, R., \& Araujo-Pinzon, P. (2019). Resource-Based View and SMEs performance exporting through foreign intermediaries: the mediating effect of management controls. Sustainability, 11(3241), 1-26. https://doi.org/10.3390/su11123241

Scafarto, V., Ricci, F., \& Scafarto, F. (2016). Intellectual capital and firm performance in the global agribusiness industry, The moderating role of human capital. Journal of Intellectual Capital, 17(3), 530-552. https://doi.org/10.1108/JIC-11-2015-0096

Sharabati, A. A. A., Naji Jawad, S., \& Bontis, N. (2010). Intellectual capital and business performance in the pharmaceutical sector of Jordan. Management Decision, 48(1), 105-131. https://doi.org/10.1108/00251741011014481

Sharma, M. (2020). Role of cooperatives in poverty alleviation of rural farmers in Nepal: empirical evidence. International Journal of Graduate Research and Review, 6(1), 5-10. 
Sushila Devi, R., Nurizah, N., Mohd Shahron, A. S., Rafedah, J., \& Farahaini, M. H. (2009). Factors influencing the performance of cooperatives in Malaysia: A tentative framework. Malaysian Journal of Co-operative Management, 5, 43-62.

Vrontis, D., Thrassou, A., \& Mat Zin, R. (2010). Internal marketing as an agent of change- implementing a new human resources information system for Malaysian Airlines. Journal of General Management, 36(1), 21-41. https://doi.org/10.1177/030630701003600102

Wang, H. L. (2014). Theories for competitive advantage. In H. Hasan (Ed.), Being practical with theory: a window into business research (pp. 33-43). Wollongong, Australia: Theori. Retrieved from http://eurekaconnection.files.wordpress.com/2014/02/p-33-43-theoriesof-competitive-advantage-theori-ebook_f inaljan2014-v3.pdf

Wang, Z., \& Cao, J. (2015). Impact of intellectual capital on firm performance: the influence of innovation capability and environmental dynamism. Twenty-First Americas Conference on Information Systems, 1-16.

Winter, S. (2003). Understanding dynamic capabilities. Strategic Management Journal, 24, 991-995. https://doi.org/10.1002/smj.318

Yảnẽz-Araque, B., Hernảndez-Perlines, F., \& Moreno-Garcia, J. (2017). From training to organizational behavior: A mediation model through absorptive and innovative capacities. Frontiers in Psychology, 8(1532), 1-22. https://doi.org/10.3389/fpsyg.2017.01532

Yao-Ping Peng, M., Zhang, Z., Yen, H., \& Yang, S. (2019). Dynamic capabilities and firm performance in the high-tech industry: quadratic and moderating effects under differing ambidexterity levels. Sustainability, 11(5004), 1-15. https://doi.org/10.3390/su11185004

\section{Copyrights}

Copyright for this article is retained by the author(s), with first publication rights granted to the journal.

This is an open-access article distributed under the terms and conditions of the Creative Commons Attribution license (http://creativecommons.org/licenses/by/4.0/). 